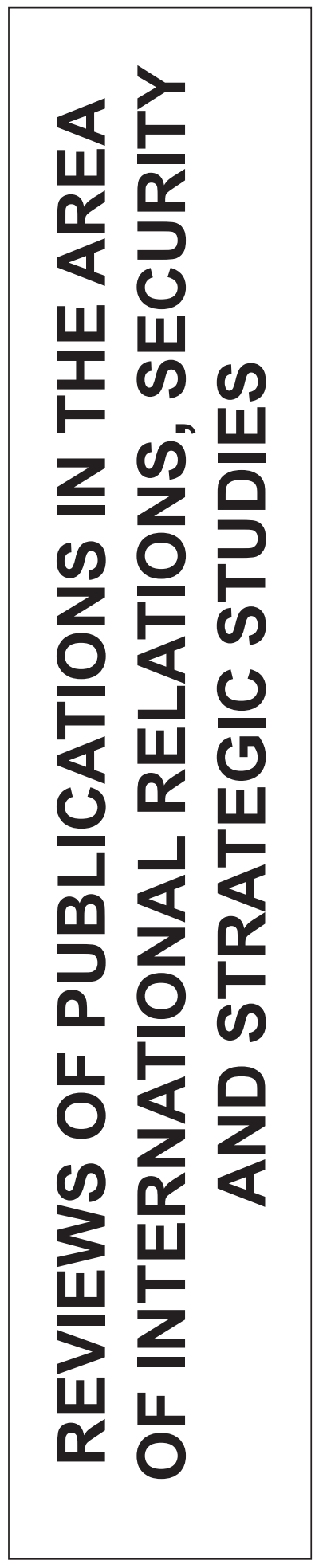





\section{SIPRI YEARBOOK 2017}

In 1969, the Stockholm International Peace Research Institute (SIPRI) started to publish a yearbook discussing global military expenditure, international arms transfers, arms production, nuclear potential, armed conflicts and multilateral peace operations. These analyses are based on the most recent information on the arms trade, peace and international security. The latest issue (Yearbook 2017) concerns 2016 and focuses on the four issues that seem crucial for the study of peace: armed conflicts and conflict management, security and development, military spending and armaments, nonproliferation, arms control and disarmament. Due to the size of the SIPRI Yearbook 2017, this study discusses the most important topics discussed in the Yearbook, in chronological order.

The Introduction to Yearbook 2017 presents the trend which was discussed in the preceding SIPRI Yearbooks (2015 and 2016), namely the growing number of conflicts breaking out across the globe and the increasing pace of armament. As in 2015, 2016 witnessed ongoing and abrupt changes, but "the balance sheet seemed to be tipping towards the negative amid growing unease about the durability of key parts of the international security architecture." This pessimism is rooted in the continuously negative global indicators for peace and security, namely: more military spending, increased arms trade, more violent conflicts and continuing advancements in military technology. Additionally, multilateral and bilateral arms control agreements, which are the fundamental components of the armament control system at present, are politically undermined due to mounting strategic competition between the major powers. The chaos is further augmented by the United Kingdom voting to leave the European Union and the election of Donald Trump as US President, whose interpretation of the situation is somewhat atypical.

Importantly, this destabilization is not related to the classic clash between the US and the Russian Federation, but is spread between other powers, particularly the People's Republic of China. 2016 saw conflicts in the Middle East, parts of Africa and a stalemate in Eastern Europe. In 2016, North Korea and its nuclear program or, to be more precise, the Korean development of carriers for nuclear warheads, also contributed to instability.

The first section of the SIPRI Yearbook 2017 addresses armed conflicts and conflict management, or rather describes the matters discussed in the Introduction in more detail. Firstly, the events in 2016 confirmed the reversal of the post-Cold War trend, identified one year earlier. Although the number of active armed conflicts decreased from 52 to 49 in 2016, this number remains high compared with the period 2007-2013. 
After the collapse of the Soviet Union, the two periods 1990-92 and 2014-2016 constitute two distinct peaks; the latter can be explained by the activities of Islamic State (ISIS). Of the 49 active conflicts in 2016, two were fought between states (IndiaPakistan and Eritrea-Ethiopia) and the other 47 went beyond this pattern, following that of a hybrid war. Islamist organizations constituted one of the warring factions in as many as 13 of these conflicts (e.g. Afghanistan-IS, Libya-IS, Turkey-IS, Syria-IS). There were three instances of de-escalation (Nigeria, Ukraine and Pakistan). Africa, as usual, remained the region with the highest number of conflicts in 2016 (19 active conflicts), followed by Asia (15 conflicts) and then by the Middle East (10), Europe (3) and the Americas (2). The peace agreement concluded in Columbia in 2016 is particularly noteworthy and it shows that Latin America is soon likely to have no active armed conflicts. On the other hand, religious tension increased around the world, with one-third of Islamist armed conflicts taking place in the Middle East and North Africa, one third in sub-Saharan Africa, and the rest in Asia. This is evidence of the trend of the military activation of Islamism. Secondly, the Middle East and North Africa (MENA) remained at the heart of global security concerns throughout 2016. The main factors involved chronic insecurity and persistent susceptibility to armed conflict (that is, governance failures in most Arab countries and the consequences of the 2003 invasion of Iraq). In 2016, at least 7 of the 16 countries in the region used military force in combat on their own territory, and 11 used it on the territory of other countries. A key element in MENA's security profile is the aftermath of the 2011 Arab Spring, as only Tunisia is still maintaining domestic stability at an acceptable level. Thirdly, the war in Syria has resulted in mass relocation: half of the population (over 11 out of the 22 million) have been relocated: about 4.8 have been forced to flee the country, and 6.3 million have been internally displaced. Similarly, Libya has been seeking stability in vain since 2011. Yemen has become the setting of an armed conflict between Saudi Arabia and Iran. Islamic State has suffered setbacks in the Middle East, but has become very active outside the region. At present, Western Europe is experiencing an axiological-religious clash, as evidenced by terrorist attacks that have been intensifying since 2016. Fourthly, the Middle East has become an exceptionally heavily armed region, where military expenditure of individual countries is a significant element of (or rather burden to) their respective budgets. The absence of exact (official) data reflects a lack of transparency and accountability in military matters. Saudi Arabia remains the largest arms importer, while arms imports to the entire region rose by $86 \%$ between 2007-11 and 2012-16, accounting for 29\% of global arms imports in 2012-16 and increasing the military capability of selected countries. The western powers selling the arms are likely to be contributing to increasing instability and violent conflicts. Fifthly, Europe had been convinced that conflicts that had been smoldering on the continent for centuries had been resolved by peace projects, such as those launched by the EU, OSCE, the Council of Europe, and so on. Unfortunately, this region was not spared armed conflicts, which have actually become its inherent feature, as evidenced by the escalation of violence in post-Soviet territory. An attempted coup d'état in Turkey additionally led to realignment in this region, in particular in Russian-Turkish and EUTurkish relations. Sixthly, 2016 marked a culmination in conflict management, or to be more precise, the number of peace missions has leveled out. Compared with 2015, the 
number of peace missions fell by 1 to 62 , and the total number of personnel declined by $6 \%$ to 153,056 , continuing a downward trend that began in 2012 . Africa remained the primary beneficiary of peace operations, a trend which is likely to continue given the anticipated further stabilization in Burundi and Libya, among others. However, replacing multilateral collaboration with unilateral pursuit of individual interests (state egoism) in 2016 led to disputes about the financing of these peace missions. States (donors) had increasing demands about the mission goals, while becoming less generous. The impotence of the international community in the protection of civilians was made painfully clear in Syria, Ukraine and, to a lesser extent, Sudan.

The second section of the SIPRI Yearbook 2017 addresses the issues of security and development. Its main theme concerns applying a comprehensive legislative framework to the endeavors to improve the quality of life in communities burdened by armed conflicts. Firstly, the foremost aim is to achieve the 17 goals by 2030, as provided for in the Agenda for Sustainable Development. This process reflects the fact that the UN concept of sustaining peace based on the three pillars of peace and security, development and human rights is a continuous process that may take decades. It will replace the sequential approach to conflict that is often delayed, especially in terms of prevention, response and management. In order to achieve this aim, it is vital to understand the impact of armed conflicts on states and the recovery period typically required. On average, a civil war lasts 7 years, but it takes 14 years to recover from one economically, and it can take 25 years to return to the pre-war state. Historically, this is exemplified by Cambodia, Laos and Vietnam, and today - by the backwardness of Libya, South Sudan, Yemen or Syria. Secondly, at the May 2016 World Humanitarian Summit (WHS), over 3,100 representatives of states and institutions committed themselves in core areas, such as the conditional ending of conflicts and better targeted funding of humanitarian assistance; yet the concept of conflict prevention remains mostly aspirational. Thirdly, in 2016 the high rate of relocation was maintained and the number of forcefully displaced persons exceeded 60 million, which resulted from the protracted crises in Syria, Afghanistan, Yemen and South Sudan. The greatest challenge was the concentration of forcefully displaced persons in confined geographical spaces (in a city, along a transit route, at a border), resulting in temporary overcrowding and the associated problems, such as the lack of adequate protection, healthcare, food supplies or education. The adverse impact of this phenomenon was particularly prominent in the countries which were unable to mitigate the aftermath of these mass movements of people and absorb them (due to insufficient resources and potential). Fourthly, climate change also has multifaceted short-, medium- and long-term impacts which affect human settlements, in particular in terms of social, energy and food security, as well as the security of statehood as such. Shortages increase the risk of violent conflict breaking out, and there are certain links between climate change and the formation of the defense and development policy of the states which are most threatened by it. In East Africa, four complementary mechanisms linking climate change to conflict have been identified: worsening living conditions; migration and changing pastoral mobility patterns; activation of armed groups; and exploitation of local grievances by the elite. It is therefore the goal for the near future to mitigate the impact of climate change on quality of life by forging adequate resolution mechanisms for conflicts of interests. 
The third section of the SIPRI Yearbook 2017 features analysis of military expenditure and armaments. Firstly, world military expenditure was estimated at $\$ 1,686$ billion in 2016, equivalent to $2.2 \%$ of global gross domestic product or $\$ 227$ per person. Total global expenditure in 2016 was roughly constant compared to 2015, being only $0.4 \%$ higher in real terms. Military expenditure in North America saw its first annual increase since 2010, while in Western Europe spending was up by $2.6 \%$ on 2015 . A similar trend continued in Asia, Oceania and Eastern Europe, in contrast to Africa, Latin America and the Middle East (in those countries for which data is available). With a total of $\$ 611$ billion (growth by $1.7 \%$ compared with 2015 ), the United States remained the largest military spender in 2016. It is noteworthy that this is the first annual increase since the 2010 peak. Secondly, the volume of international arms transfers grew by $8.4 \%$ between $2007-11$ and 2012-16. The five largest suppliers in 2012-16 were the major global powers - the United States, Russia, China, France and Germany ( $74 \%$ of the total volume of exports), and there are no signs of any major change in the near future. Thirdly, at the regional level, the flow of arms to the Middle East grew by $86 \%$ between 2007-11 and 2012-16, while the flow of arms to Asia and Oceania rose by $7.7 \%$. By contrast, the flow of arms to Europe decreased notably (by $36 \%$ ), as it did for the Americas (by 18\%) and Africa (by 6.6\%). The level of transparency of arms transfers remained the same, which means that the number of states reporting arms imports and exports to the United Nations Register of Conventional Arms remained low, while the mandatory reporting under the Arms Trade Treaty (ATT) started reasonably well in 2016. Fourthly, at the start of 2017, nine states (the United States, Russia, the United Kingdom, France, China, India, Pakistan, Israel and the Democratic People's Republic of Korea) possessed approximately 14,935 nuclear weapons, of which 4,150 were deployed with operational forces, and nearly 1,800 of which were kept in a state of high operational alert. Overall, the trend concerning the number of nuclear warheads is stable and their inventories continue to decline. This is primarily due to reductions made by the USA and Russia, which together account for approximately $92 \%$ of nuclear weapons globally. Transparency on the status and size of the nuclear arsenals and rocket tests launched remains at a low level, as was the case in 2015.

The analysis presented in the final, fourth section of the SIPRI Yearbook (non-proliferation, arms control and disarmament) focuses on the most important step, namely designing a legally binding instrument of nuclear disarmament. Firstly, the elimination of nuclear weapons was hoped for, which turned out to be wishful thinking (boycott of the Nuclear Club). Secondly, in 2016 US-Russian disarmament came to a standstill due to a deterioration in mutual relations. The new START agreement continued to be implemented, but no deeper cuts in the strategic nuclear forces of the two states were made. Thirdly, Iran continued to implement the provisions of the Joint Comprehensive Plan of Action (JCPOA) covering limitations on its nuclear energy program. Fourthly, there were continued instances of the alleged and confirmed use of chemical weapons in Iraq and Syria and four major reports were issued in 2016, which identified the parties responsible for the use of chemical weapons; some states (albeit a minority) questioned these reports. Fifthly, the International Committee of the Red Cross (ICRC) provided guidance on how to implement the principles of existing conventions. The most important guidance addresses the matter of how to apply the Geneva Convention 
to non-international armed conflicts. Sixthly, states failed to agree detailed measures to be taken on small arms and light weapons (SALW) or the use of explosive weapons in populated areas (EWIPA), including armed unmanned aerial vehicles, to increase the transparency of their use. Seventhly, states continued their work on the Arms Trade Treaty (ATT), in particular in relation to the role and functioning of the system, the ATT Secretariat as well as other technical matters. Eighthly, in 2016 there were 38 multilateral arms embargoes in force (no new embargoes were imposed in 2016): 15 imposed by the United Nations, 22 by the European Union and 1 by the League of Arab States. Most of these embargoes only cover conventional arms. However, the embargoes on Iran, North Korea, and Russia also cover exports of dual-use goods (at the same time, work continued on defining dual-use goods and expanding supervision over them).

The final section of the SIPRI Yearbook traditionally features annexes (synthetic and chronological).

Graph 1. Regional distribution and total number of armed conflicts, 2007-2016

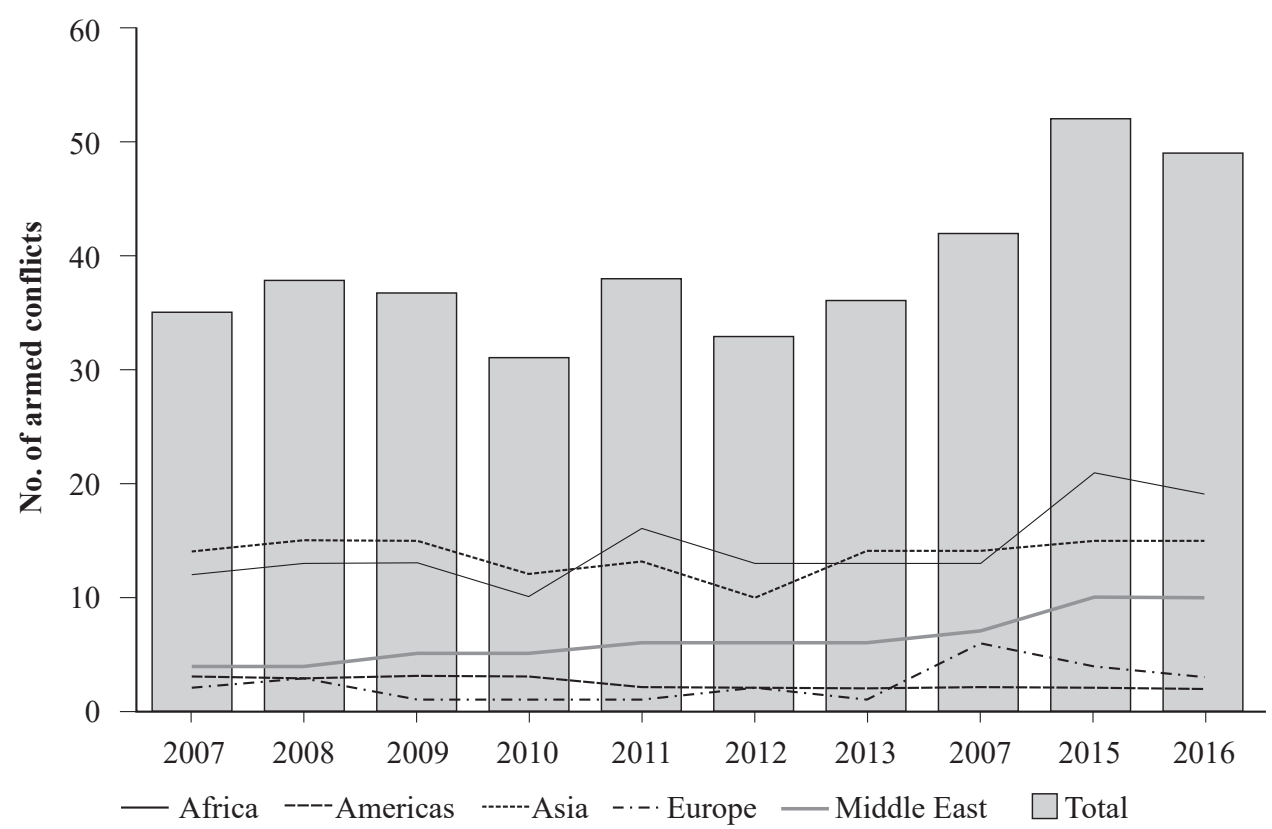

Source: SIPRI Yearbook 2017 Summary: 3.

Table 1

The main exporters and importers of conventional weapons, 2012-2016

\begin{tabular}{||l|c|l|c||}
\hline \multicolumn{1}{|c|}{ Exporter } & Global share (\%) & \multicolumn{1}{c|}{ Importer } & Global share (\%) \\
\hline \multicolumn{1}{|c|}{1} & 2 & \multicolumn{1}{c|}{3} & 4 \\
\hline 1. USA & 33.0 & 1. India & 13.0 \\
\hline 2. Rusia & 23.0 & 2. Saudi Arabia & 8.2 \\
\hline 3. Chna & 6.2 & 3. UAE & 4.6 \\
\hline 4. France & 6.0 & 4. China & 4.5 \\
\hline 5. Germany & 5.6 & 5. Algeria & 3.7 \\
\hline
\end{tabular}




\begin{tabular}{||l|l|l|c||}
\hline \multicolumn{1}{|c|}{1} & \multicolumn{1}{c|}{3} & 4 \\
\hline 6. UK & 4.6 & 6. Turkey & 3.3 \\
\hline 7. Spain & 2.8 & 7. Australia & 3.3 \\
\hline 8. Italy & 2.7 & 8. Iraq & 3.2 \\
\hline 9. Ukraine & 2.6 & 9. Pakistan & 3.2 \\
\hline 10. Israel & 2.3 & 10. Viet Nam & 3.0 \\
\hline
\end{tabular}

Source: SIPRI Yearbook 2017 Summary: 15.

Graph 2. Military expenditure by the five largest spenders in the Middle East, 2007-2016

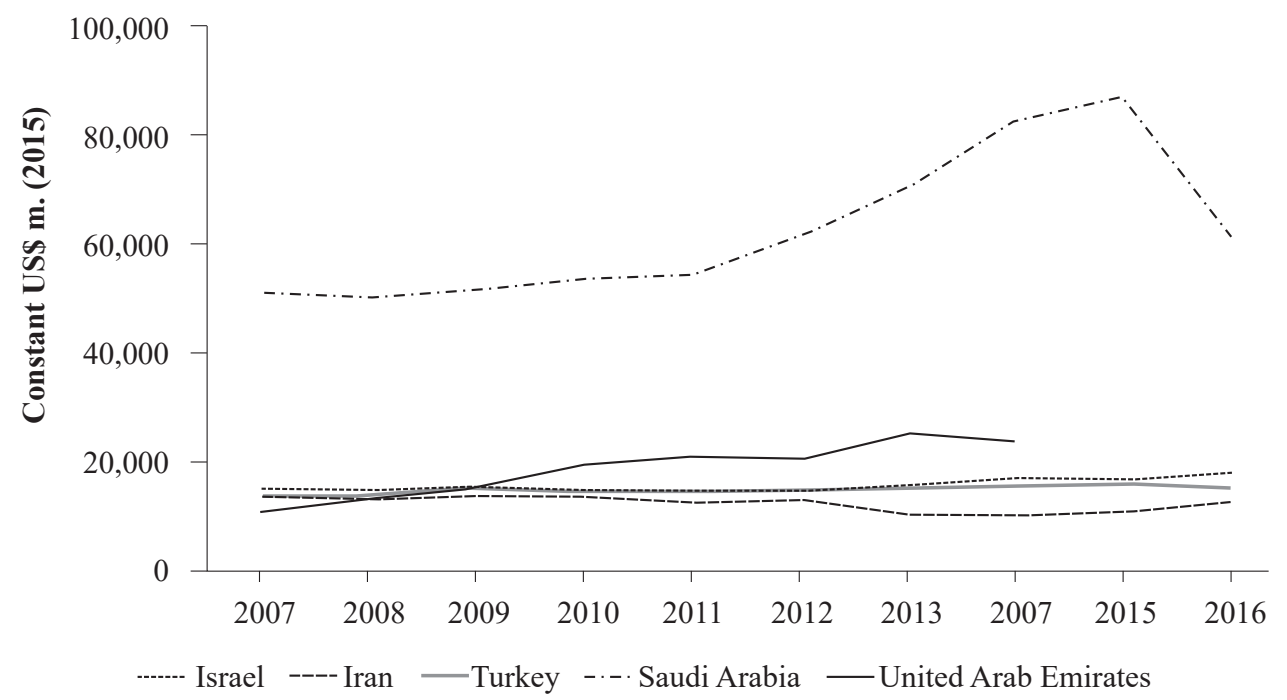

Source: SIPRI Yearbook 2017 Summary: 5.

\begin{abstract}
The study is dedicated to the most important trends confirmed by current knowledge in the SIPRI Yearbook 2017. SIPRI annually issues a study which shows a comprehensive picture of the activity of international actors in terms of world military expenditure, international arms transfers, arms production, nuclear forces, armed conflicts and multilateral peace operations, as well as the promotion of security and development.
\end{abstract}

Keywords: Stockholm International Peace Research Institute, SIPRI Yearbook 2017, disarmament, military expenditure

\title{
SIPRI YEARBOOK 2017
}

\section{STRESZCZENIE}

Komentarz poświęcono SIPRI Yearbook 2017 i zawartym w nim najważniejszym tendencjom potwierdzonych najbardziej aktualną wiedzą. Coroczne opracowanie w kompleksowy sposób 
ukazuje aktywność aktorów międzynarodowych w kwestii światowych wydatków zbrojeniowych, międzynarodowych transferów broni, produkcji zbrojeniowej, sił nuklearnych, konfliktów zbrojnych, multilateralnych operacji pokojowych czy samej działalności na rzecz bezpieczeństwa i rozwoju.

Słowa kluczowe: Sztokholmski Międzynarodowy Instytut Badań nad Pokojem, Rocznik SIPRI 2017, zbrojenia, rozbrojenie, wydatki wojskowe 
